\title{
Bo Fibiger - Nekrolog
}

\section{Bo Fibiger}

$1945-2008$

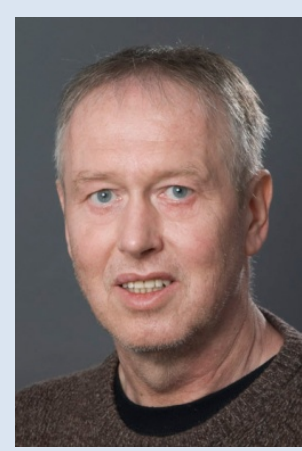

Dette tidsskriftnummer er tilegnet mindet om Bo Fibiger, som døde den 20. oktober 2008. Bo spillede en afgørende rolle for opbygningen af forskningen $i$ IKT og læring på Institut for Informations- og Medievidenskab ved Aarhus Universitet. Siden slutningen af 1980'erne ligger den overvejende del af hans videnskabelige publikationer inden for dette emne, bl.a. i forlængelse af forskningsprojekterne VENUS (Video, Edb, Narrativitet og UndervisningsSystemer) 1989-94, Pædagogik i Distribueret Undervisning 1995-97 og Distributed Education 1998-2001. Parallelt hermed var Bo en aktiv deltager i en række udviklingsprojekter både på nationalt og internationalt plan. Fokus for Bos forskning inden for området har især været på den didaktiske udfordring i at designe medierne og deres anvendelse på en måde, der støtter læreprocessen. Samme fokus findes også i artiklen i dette tidsskriftnummer, som blev hans sidste.

Samtidig med interessen for de teoretiske problemstillinger inden for læringsområdet var Bo også en praktiker, der elskede at se tingene udvikle sig. Han ønskede altid at anvende sin nyvundne videnskabelige indsigt til at forandre uddannelserne. Sammen udviklede og gennemførte vi over en ti-årig periode i 90'erne modulet "Medier, kommunikation og formidling" inden for suppleringsuddannelsen "Retorik, kommunikation og formidling" udbudt som fjernundervisning på Jysk Åbent Universitet. Det var erfaringerne fra ovennævnte forskningsprojekter som her blev udmøntet i praksis. Samme ildhu lagde han også for dagen da han gik ind i udviklings- og styringsgruppen for 
Masteruddannelsen i IKT og Læring. Uddannelsen er et samarbejde mellem 5 forskellige institutioner (efter universitetsfusionerne reduceret til 4). Gennem alle årene har Bo repræsenteret Aarhus Universitets humanistiske fakultet, og han har med sit ansvar for modulet om "didaktisk design" været en central drivkraft i introduktionen og udviklingen af dette begreb i en dansk sammenhæng. Som anerkendelse af hans store indsats og med troen på hans evner til at fortsætte videreudviklingen blev han i september 2008 udnævnt til adjungeret professor ved Aalborg Universitet, hvor masteruddannelsen formelt er tilknyttet. Det var også Bos interesse for uddannelsesudvikling der fik ham til i begyndelsen af 2007 at sige ja til posten som den første formand for det fælles studienævn for alle uddannelserne hjemmehørende på Institut for Informations- og Medievidenskab.

Der er skrevet andre nekrologer over Bo umiddelbart efter hans død, hvor fokus har været på andre sider af hans store indsats på mange områder, bl.a. hans politiske arbejde som medlem af kommunalbestyrelser og amtsråd, samt hans administrative og universitetspolitiske arbejde. Fælles for dem alle har været en understregning af Bos pragmatiske vilje og diplomatiske evne til altid at søge efter en løsning på problemerne. Jeg kan fuldt ud tilslutte mig den karakteristik og dertil tilføje at Bo også var drevet at en god portion idealisme, hvor det altid var sagen der stor i centrum, aldrig hans egen karriere.

Bo er savnet både som ven, kollega, forsker, administrator og underviser.

Århus, juli 2010

Jørgen Bang 